\title{
Effectiveness of a Collaborative Platform for the Mastery of Competencies in the Distance Learning Modality during COVID-19
}

\author{
Sara Domínguez-Lloria ${ }^{1}\left(\mathbb{D}\right.$, Sara Fernández-Aguayo ${ }^{2}$, José-Antonio Marín-Marín ${ }^{3}[\mathbb{C}$ \\ and Myriam Alvariñas-Villaverde ${ }^{4, *}$ (D) \\ 1 Department of Applied Didactics, University of Santiago de Compostela, \\ 15782 Santiago de Compostela, Spain; saradominguez.lloria@usc.es \\ 2 Department of Didactics and School Organization, University of Vigo, 36310 Pontevedra, Spain; \\ sfaguayo@uvigo.es \\ 3 Department of Didactics and School Organization, University of Granada, 18071 Granada, Spain; \\ jmarin@ugr.es \\ 4 Department of Special Didactics, University of Vigo, 36310 Vigo, Spain \\ * Correspondence: myalva@uvigo.es
}

\section{check for} updates

Citation: Domínguez-Lloria, S.; Fernández-Aguayo, S.; Marín-Marín, J.-A.; Alvariñas-Villaverde, M. Effectiveness of a Collaborative Platform for the Mastery of Competencies in the Distance Learning Modality during COVID-19. Sustainability 2021, 13, 5854 . https://doi.org/10.3390/su13115854

Academic Editor:

David González-Gómez

Received: 22 April 2021

Accepted: 21 May 2021

Published: 23 May 2021

Publisher's Note: MDPI stays neutral with regard to jurisdictional claims in published maps and institutional affiliations.

Copyright: (C) 2021 by the authors Licensee MDPI, Basel, Switzerland. This article is an open access article distributed under the terms and conditions of the Creative Commons Attribution (CC BY) license (https:/ / creativecommons.org/licenses/by/ $4.0 /)$.

\begin{abstract}
The need to adapt to new learning scenarios due to the impact of COVID-19 on our education system is undeniable. This fact means that we must adapt teaching to non-face-to-face scenarios in order to adapt the teaching processes without the students losing the acquisition of competences. The aim of this study is to evaluate the effectiveness of a digital application for the development of competences of primary education undergraduate students in a non-face-to-face teaching context derived from the pandemic through a service-learning project. To achieve this objective, a specific programme was designed using a collaborative platform. Numerous instruments were used to assess the acquisition of basic, specific, general and transversal competences. On a quantitative level, the Teamworks Skills Questionnaire and an evaluation rubric were used, and on a qualitative level, a student field diary, a survey to measure satisfaction and an observational record were used. The main results show that after the implementation of the use of the platform, both the level of competence of the students and their satisfaction with the project were very high and that the impact on their training was very positive. Among the main conclusions, we highlight that the use of this type of platform allows students to acquire competences in non-classroom contexts. On the other hand, we conclude that training in the use of digital tools in initial teacher training is necessary for good professional performance. On the other hand, this experience allowed future teachers to realise the need to master new technologies in order to be able to adapt to the new needs that different educational scenarios pose in the information society.
\end{abstract}

Keywords: teaching skills; effectiveness; distance learning; COVID-19; collaborative platform; ITC; teacher training; service learning

\section{Introduction}

The global pandemic caused by COVID-19 has changed the strategies that have been traditionally used in teaching-learning processes towards online or hybrid teaching formats in universities around the world. The need to facilitate students' mastery of the competences described in their respective university degrees has forced teaching staff to use tools that guarantee the acquisition of these competences, which in turn facilitate employability and enable them to respond to the needs they will encounter in the workplace $[1,2]$.

The development of competences in university students is one of the basic objectives of the university, since it is here that highly qualified professionals are trained to solve the problems that society poses to them [3]. López-Ruiz [4] states that students' competencybased learning facilitates the development of both professional and personal skills. 
In the case of teacher training, it is necessary to respond to the new situation by enabling students to acquire competences by increasing their motivation and responsibility in the teaching-learning process. Implementing projects that enable the mastery of competences makes it necessary to create innovative environments that favour the employability of graduates and, therefore, the socioeconomic development of a country [5]. Villa and Poblete [6] affirm that training must bring together aspects that are in line with today's reality: flexibility, mobility and transferability. The need to train in competences puts the student in a position to cooperate, communicate, make decisions, create and innovate. These competences make the teacher a versatile and flexible professional with the capacity for continuous adaptation to the socio-occupational environment [7]. Along the same lines, García-Peñalvo et al. [8] affirm that a more participative and collaborative methodological context is necessary to guarantee the acquisition of transversal competences and that these are not affected by non-presence.

In addition, the need for adequate digital competence for educators has been critical to avoid disruptions in the teaching-learning processes resulting from the COVID-19 pandemic [9].

Numerous studies $[10,11]$ have addressed this demand for prospective teachers in faculties of education, as well as the demand for active teachers through professional development programmes. COVID-19 has arguably emphasised the importance of teacher professional development for online and blended learning [12].

Therefore, the adaptation to the use of new technologies in the current context is undeniable and a methodological change is needed on the part of the teacher to incorporate the use of new technologies in the classroom [13].

The authors of [14] state that digital transformation implies changes that allows for new operational and educational models that transform the operations, strategic directions and value of institutions. Janssen and Bodemer [15] assert that ICTs favour collaborative knowledge construction, where students shape robust processes of meaningful learning through the exchange of information and agreements among peers.

Furthermore, we must bear in mind that learning through mobile devices facilitates the construction of knowledge, the resolution of learning problems and the development of diverse skills or abilities in an autonomous and ubiquitous way [16,17], affirming that technological and digital development has become a medium that influences the construction and interpretation of the reality that surrounds us. Apps are intuitive, useful and simple resources for learning. Villalonga and Marta-Lazo [18] praise applications for mobile devices that facilitate tools, activities and sources of information that are used in everyday life for the purpose of learning. This is what they call "learning", and they frame these apps in what they call a personal learning environment (PLE).

For this reason, we consider, along with the authors of [19], that a change in the way of teaching that adapts to the new reality is fundamental, and specifically, in order to develop the possibility of establishing digital competence in students, the incorporation of mobile devices in classroom activities is necessary.

When technology is combined with an active methodology such as service learning (SL), the advantages for students tend to be greater. SL enables the dual purpose of university education: training for work and training for active citizenship [20]. Students learn and develop active participation in providing services and solving community problems [21].

We believe that this methodology allows teachers to optimise students' academic performance, improve their social competences and civic skills, promote their freedom to organise their studies and their responsibility for them and reinforce the social dimension of the university [22-25].

SL brings students, teachers and the community together, so that all become teaching resources and problem solvers. It enhances academic and real-world learning, instilling in students a sense of civic engagement and responsibility [26].

Numerous research studies support the findings that active participation in servicelearning projects clearly enhances learning acquisition in a meaningful and lasting way [27-30]. 
Bearing these premises in mind, the aim of this study is to evaluate the effectiveness of a digital application for the development of competences, in a context of distance learning due to the pandemic derived from COVID-19, through a service-learning project.

\section{Problem Statement}

Competences linked to the mastery of skills in real environments are vital for the employability of future university students [31]. As a consequence of the situation resulting from the COVID-19 pandemic, a large part of university students has seen their teaching activity transferred to the non-classroom context. This context is mainly detrimental to the mastery of transversal competences such as adaptability, teamwork or reflective/critical and creative problem solving, which are essential for the training of future teachers.

In response to this situation, an experience has been proposed to achieve the mastery of competences with students from the University of Santiago de Compostela in the bachelor's degree in primary education with a mention in music education.

The main objective of the experience is to find out the degree of development of the competences of the subject "Processes and didactic projects in music education" through the use of the digital application MIRO.

For this purpose, a research question was established:

RQ1: Does a collaborative application enable students to achieve adequate mastery of competences?

\section{Materials and Methods}

The problem under study was approached from an ethnographically oriented case study methodology, from a sociocritical perspective, using mixed procedures. In recent years, the case study has increasingly been used as a mixed method approach, combining both quantitative and qualitative procedures [32,33]. The specific instruments used in the research are described in the programme evaluation.

\subsection{Description of the MIRO App}

For the selection of the application, the characteristics and needs of the programmed activities were taken into account. After a research process, it was decided to select the MIRO application as it had all the necessary characteristics to carry out the project in a fully telematic way, incorporating numerous functionalities. We also considered the importance of students acquiring both digital and collaborative skills that would allow them to join a new normality that will never be the same as in the pre-pandemic era in the classroom, incorporating tools that would allow them to work virtually.

Among the most outstanding features, we can comment that this application allowed teachers to moderate unlimited groups. It also made it possible to keep a very detailed record of time and student interaction. The development of the boards made it possible to observe the process of content creation in a step-by-step manner, not one focused on the final product. As a contribution to the students, we observed that it had a very interactive and intuitive interface and a series of built-in tools such as the possibility of adding all kinds of external resources, voting and communication systems within the application itself, such as videoconferencing and chat to carry out their interactions.

\subsection{Participants}

This project was implemented in the first semester of the academic year 2020/21. The participants of the project were 21 students with an average age of 24 years.

All students study at the Faculty of Education Sciences at the University of Santiago de Compostela. Overall, $76.2 \%$ of the participants were women while $23.8 \%$ were men. The collaborative work was carried out for a service-learning project in the subject "Processes and projects in music education". This project was carried out continuously since 2018, and because of the COVID-19 pandemic, it needed to be restructured to adapt to the needs of social distancing. 


\subsection{Instruments}

The Teamworks Skills Questionnaire (TSQ) was used to assess the acquisition of transversal and specific skills. This questionnaire has six factors for measuring teamwork skills habits: coordination, decision making, leadership, interpersonal skills, adaptability and communication [34]. This questionnaire is a tool for indirect measurement of transversal teamwork competencies and has already been used in various contexts $[34,35]$.

Additionally, for the evaluation of competence acquisition, an ad hoc evaluation rubric was implemented that allowed us to assess specific, basic, general and transversal competences. The rubric is made up of 16 items that are related to the competences and each item has 4 achievement indicators for its assessment. Specifically, four items assess the specific competences, five items focus on the assessment of the general competences, four items were developed for the assessment of the basic competences and the remaining three items assess the transversal competences.

To determine student satisfaction, an ad hoc survey was carried out to find out their opinion about the experience, perceptions and suggestions [36], consisting of 16 questions. The first two questions asked the gender and age of the participants, and the remaining questions were divided into six Likert-type questions (1-5), five yes/no questions and three open questions.

The acquisition of general and transversal competences was assessed by means of an individual field diary kept by the students. In this diary, each student recorded his/her work process, the difficulties encountered, the way of resolving them, proposals for improvement and a personal assessment of his/her work process.

In addition, the teacher recorded the general assessment of the activity in the observational register according to different parameters such as compliance with deadlines, the number of critical incidents occurring during the process and the quality of the work carried out. All of this made it possible to monitor the acquisition of the competences that were to be acquired.

Table 1 shows the relationship between the instruments used, their objective and the proportion they represented in the students' marks.

Table 1. Data collection instruments.

\begin{tabular}{|c|c|c|}
\hline Instrument & Objective & Weighting \\
\hline Evaluation Rubric & $\begin{array}{c}\text { To assess the acquisition of specific, basic, general and } \\
\text { transversal competences. }\end{array}$ & $60 \%$ \\
\hline Student field diary & $\begin{array}{c}\text { To assess the acquisition of general and transversal } \\
\text { competences. }\end{array}$ & $25 \%$ \\
\hline Observational register & Recording critical incidents. & $0 \%$ \\
\hline $\begin{array}{l}\text { Teamworks Skills } \\
\text { Questionnaire }\end{array}$ & $\begin{array}{l}\text { Determine the degree of improvement in the acquisition } \\
\text { of specific and transversal competences of students. }\end{array}$ & $15 \%$ \\
\hline Satisfaction Survey & $\begin{array}{l}\text { To find out the level of student satisfaction with the } \\
\text { programme. }\end{array}$ & $0 \%$ \\
\hline
\end{tabular}

\subsection{Procedure}

Before data collection, the research process was explained to the students, and they all signed the informed consent form. The ethical standards recognised by the Declaration of Helsinki (Hong Kong revision, September 1989) and in accordance with current Spanish legal regulations governing research were followed in the development of this research.

Data analysis was performed using the SPSS 25.0 statistical package (IBM Corp., Armonk, NY, USA) and Microsoft Excel 2019. To determine whether there are differences between the results before and after the programme, the Wilcoxon non-parametric test was used given the size of the sample.

To establish the different categories of analysis, the recommendations of Krippendorf [37] were followed, starting with the determination of the units of analysis, the reduction of the data, verification of the representativeness and analysis of the data to 
establish common patterns among the results provided by all the instruments. Therefore, the categories were designed a posteriori on the basis of the results found.

The research was carried out in four stages, which are described below:

Stage 1 . In the first week, a multidisciplinary meeting was held in order to create the working groups made up of students. A total of 7 working groups were organised, each consisting of 3 members.

The aim was for all the students to interact in a multidisciplinary way, producing music didactic videos in collaboration with the orchestra of the University of Santiago de Compostela. The aim of the videos was to produce music education didactic material in an open access audio-visual format for the educational community. All the videos included a document of complementary activities that could be downloaded to complete the educational experience.

All students were presented with the evaluation rubric available on the virtual campus, which determined the detailed grading. This rubric accounted for $60 \%$ of the final mark.

Stage 2. In the second week, they were provided with a list of composers, the videos recorded by the university orchestra and the didactic contents to be developed. The different groups had the possibility of selecting two of them. In order to carry out the project, a planning schedule was established with a timetable showing the scope of the work, the dates on which it was to be delivered, the collaborative tool to be used and the teaching schedule prior to delivery. The timetable, phases and activities are detailed in Figure 1.

\section{WORK SCHEDULE}

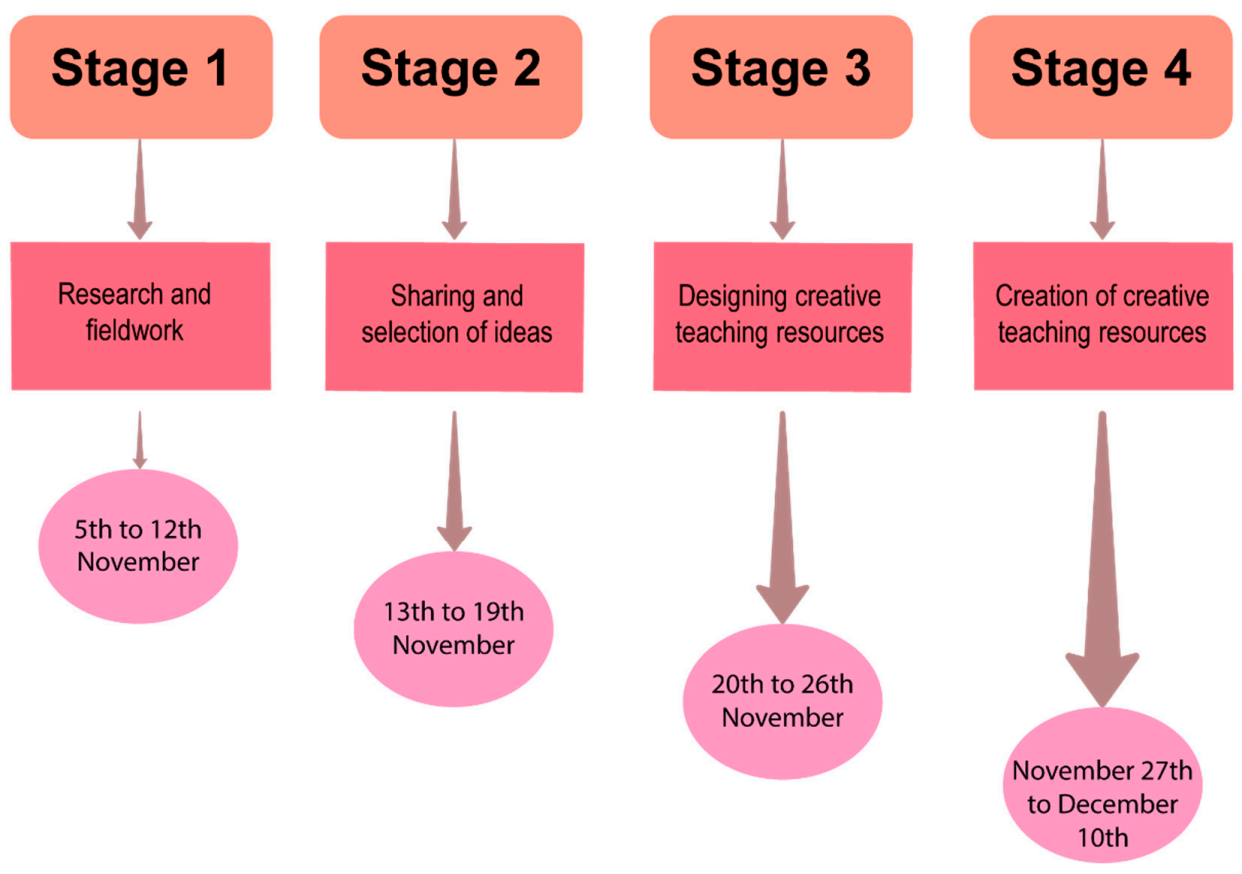

Figure 1. Timeline, tasks and phases of work.

Stage 3. Between the third and twelfth week, the collaborative work tasks began, the development of which was supported by the collaborative platform MIRO, to facilitate the sharing of information, the elaboration of didactic content and decision-making skills.

Stage 4 . In the thirteenth week, the marks were published and the group was given the option of checking the errors they obtained in each section of the evaluation rubric available from the beginning of the activity.

Finally, in the final week, the oral and public presentation of the project took place.

For this, the students had between 10 and 15 min for their presentation. 


\subsection{Programme}

The main objective of the research experience was the development of the competences of the subject "Teaching processes and projects in music education" through the use of the digital application MIRO. In addition, specific, general and basic competences of the teaching degree were included, as can be seen in Table 2.

Table 2. Relationship between objectives and competences.

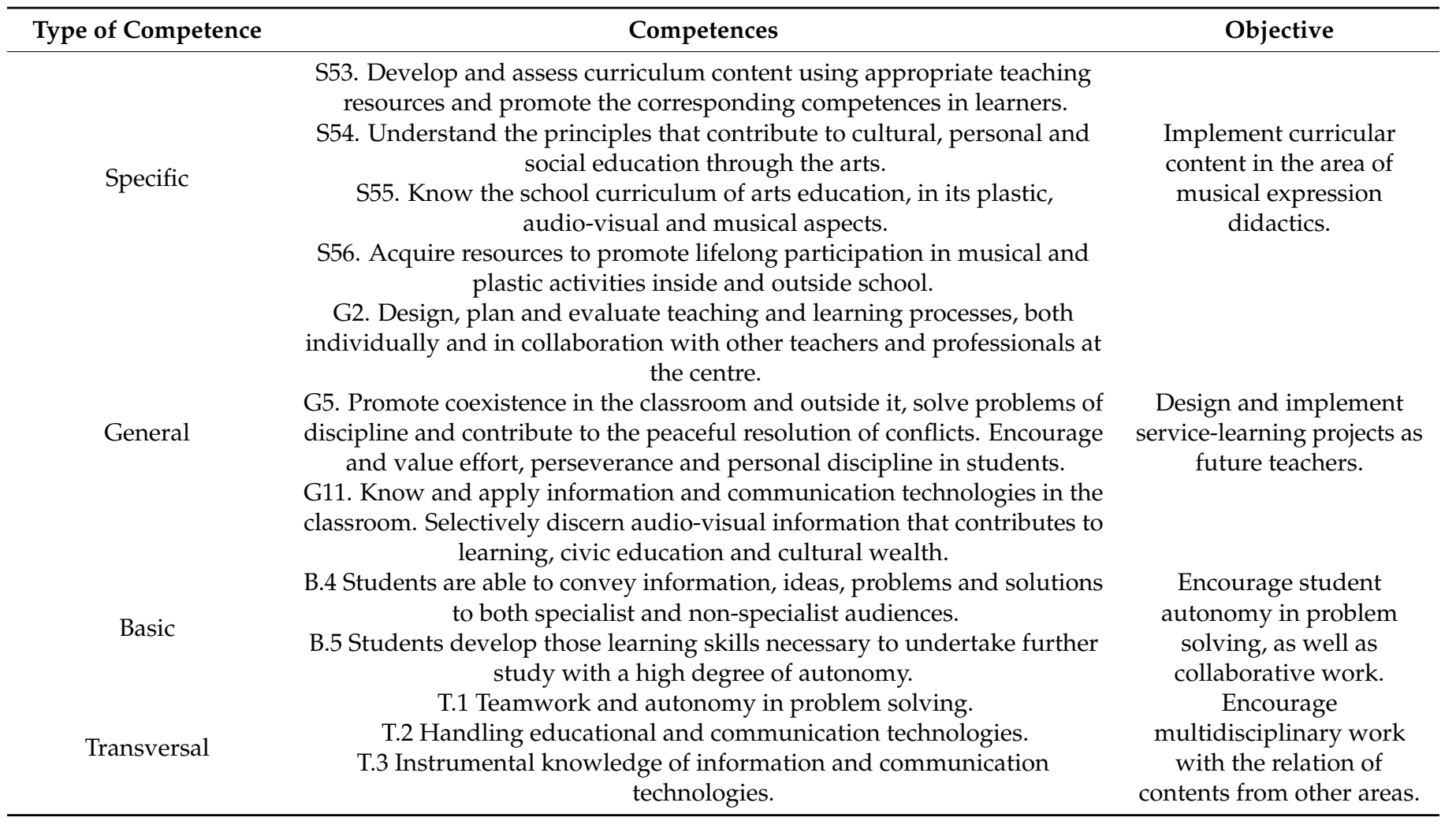

In order to achieve these goals, different activities common to the whole subject were carried out with the aim of developing a social project through the service-learning methodology and the use of different technologies such as the collaborative platform MIRO.

The programme was developed in four phases. Figure 1 shows what was worked on in each phase and the timeframe.

Training in the use and handling of the MIRO tool was carried out through video tutorials made ad hoc, which were available to students on the virtual campus of the subject. Each phase was presented with a video tutorial. The activities were designed in such a way that it is not possible to move on to the next phase without elaborating on the previous one. A collaborative panel was developed in the same way for all groups and phase 1 was developed so that they could see the possibilities of the platform. For the following phases, only the task was provided, and it was the responsibility of each group to elaborate the panel for its development.

Each phase requires a higher level of collaboration from the team in order to be carried out correctly. In phase 1 the work is individual; each member of the group does the same search for information and puts it on the board. From this activity onwards, the degree of collaboration gradually increases. The activities in each phase are described in Table 3 below. 
Table 3. Programme.

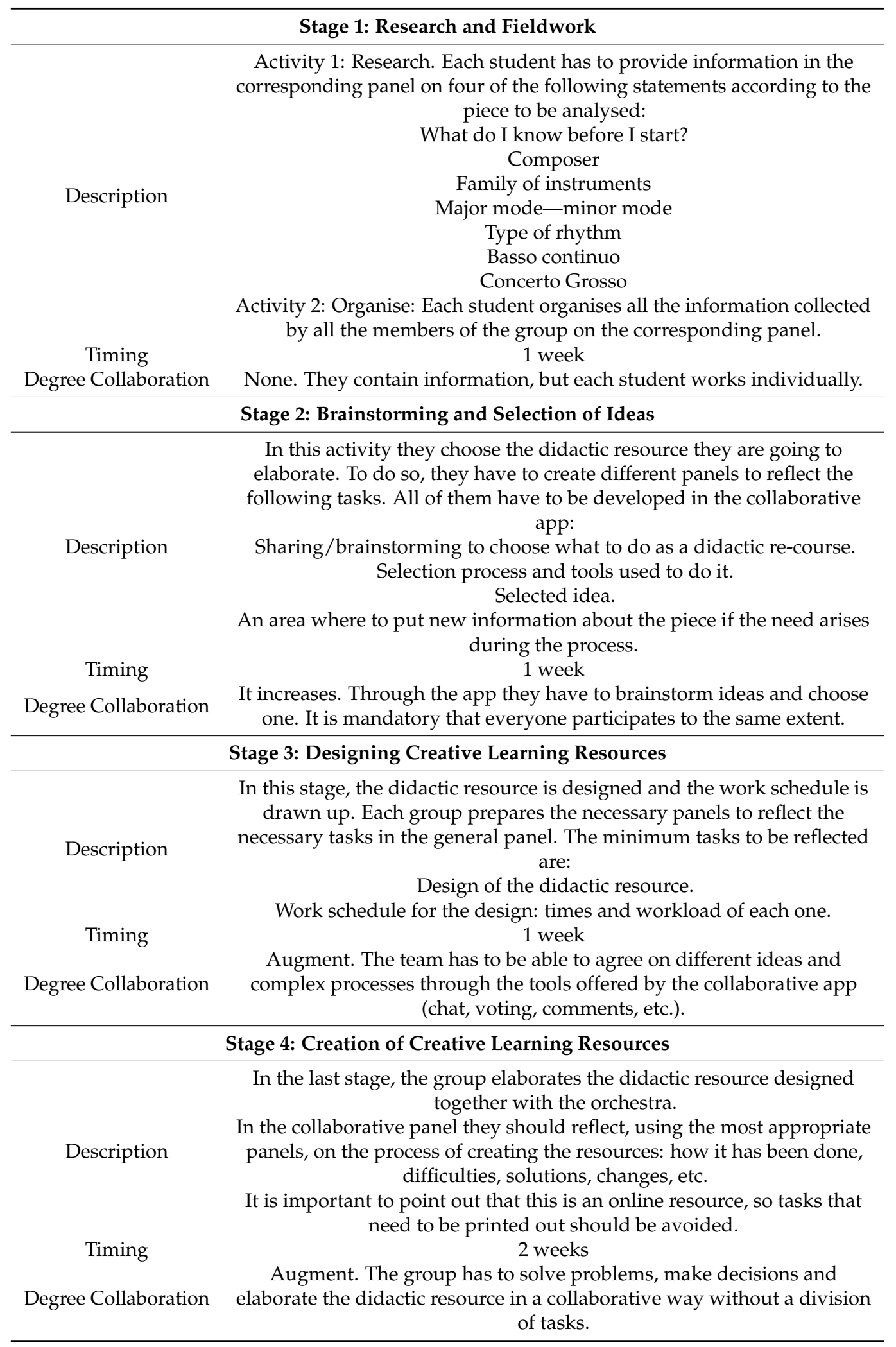

\subsection{Evaluation Techniques and Instruments}

The evaluation carried out was structured according to [38] and was divided into initial, process and final stages. 
The initial evaluation allowed us to know the initial state of the group and was carried out before the implementation of the programme. The process evaluation was carried out during the programme and the information gathered allowed us to make decisions during the process. The final evaluation was carried out at the end of the programme and allowed us to know if the objectives of the programme were achieved. Table 4 details the instruments used in each type of evaluation.

Table 4. Types and instruments of assessment.

\begin{tabular}{ccc}
\hline Evaluation & Instrument & Who Does It \\
\hline Initial & Teamworks Skills Questionnaire & Students \\
Process & Field diary & Students \\
& Observational Register & Teacher \\
\multirow{2}{*}{ Final } & Evaluation Rubric & Teacher \\
& Teamworks Skills Questionnaire & Students \\
& Satisfaction Survey & Students \\
\hline
\end{tabular}

In addition, three types of monitoring activities were carried out to monitor each group's programme and recorded in the field diary:

1. Presentation of the activities of each phase within the stipulated time.

2. In the interactive classes via videoconference, students could consult any doubts, problems and incidents they considered appropriate. The teacher advised them and gave them the necessary feedback so that they could continue to develop the project and consolidate their learning.

3. Weekly classes by videoconference or blended learning. On a weekly basis, in the interactive classroom classes, the difficulties of group work, joint organisation and the preparation and presentation of the final project were worked on.

\section{Results}

The main results are grouped into categories of analysis below for ease of interpretation.

\subsection{Level of Mastery of Competences}

The data obtained reveal an improvement in the mastery of the competences, obtaining an average mark of 8.83 out of 10 . This mark was obtained from the average of three instruments describe in Table 5. In the evaluation rubric, the average mark for the group was $8.5(10)$, while the averages for the project resolution rubric and the student's field diary both reached 9 (10).

Table 5. Average, minimum and maximum marks showing the level of improvement in competences.

\begin{tabular}{cccc}
\hline Instruments & Average Mark & Min. Mark & Max. Mark \\
\hline Evaluation Rubric & 8.5 & 6.5 & 9.5 \\
Student field diary & 9 & 8.5 & 9.5 \\
Total & 8.75 (Notable) & & \\
\hline
\end{tabular}

The level of competences acquired by the students was very high in two tests: the evaluation rubric and the field diary. The tests carried out to measure these competences were the evaluation rubric with an average mark of $\bar{x}=8.5$ (min 6.5 and max: 9.5 ) and the students' field diary with an average mark of $\bar{x}=9$ ( $\min 8.5$ and max: 9.5 ).

In order to check the effectiveness of the use of the MIRO application for the mastery of transversal competences, we carried out an analysis of related samples. As we can see, although there were no significant differences, the means in the post-test for all the competences assessed were higher. In fact, the minimum score was higher in all skills except in personal skills related to listening, respect and tolerance, empathy, leadership and problem solving (Table 6). However, only decision making was significant ( $p$-value $=0.002$ ). 
The reason why the difference is not significant may be because the sample was very low and the level of competence of the students was already very high before starting the experience.

Table 6. Wilcoxon test, $N=21$.

\begin{tabular}{cccccccc}
\hline Competences & $\begin{array}{c}\text { Average } \\
\text { Pre }\end{array}$ & $\begin{array}{c}\text { Average } \\
\text { Post }\end{array}$ & Min Pre & Min Post & Max Pre & $\begin{array}{c}\text { Max } \\
\text { Post }\end{array}$ & Sig \\
\hline Adaptability & 15.22 & 15.88 & 9.00 & 13 & 20 & 20 & 0.726 \\
Coordination & 14.11 & 15.33 & 9.00 & 12 & 20 & 20 & 0.514 \\
Decisions & 18.00 & 21.73 & 10.00 & 16 & 23 & 24 & 0.002 \\
Leadership & 17.11 & 19.44 & 9.00 & 13 & 26 & 27 & 0.342 \\
Skills & 22.55 & 21.77 & 18.00 & 16 & 24 & 24 & 0.588 \\
Communication & 23.44 & 24.55 & 14.00 & 20 & 28 & 28 & 0.674 \\
\hline
\end{tabular}

\subsection{Student Satisfaction}

The results obtained in the satisfaction survey are described below, grouped according to the type of answer. In total, $100 \%$ of the students stated that the project allowed them to work collaboratively and that the app facilitated group collaboration and improved their digital competence. Furthermore, the whole group said that after this project they realised the need and importance of training in learning and knowledge technology (LKT) tools, both on a personal level and as part of teacher training. Satisfaction with the programme was very high.

With regard to the Likert-type responses, six questions were asked with answers ranging from 1 to 5 , with 1 being negative or very little and 5 being positive or very much. Figure 2 shows the data obtained.

The overall assessment of the project, as can be seen in question 1, was positive for $100 \%$ of the students. As for the information and explanations received to be able to carry out the project, $78 \%$ of the participants indicated very positive, and the remaining $22 \%$ positive, as can be seen in question 2 . In question 3 , the app used for collaborative development was rated as very positive by $78 \%$ and positive by $22 \%$, while the remaining $22 \%$ were in between. Question 5 shows that $78 \%$ of the participants felt very good and comfortable doing the project and the remaining $22 \%$ said that they felt good. Finally, question 6 shows that $55.5 \%$ of the students say that the app facilitated collaborative work, while $44.5 \%$ of the sample gave a neutral answer. 


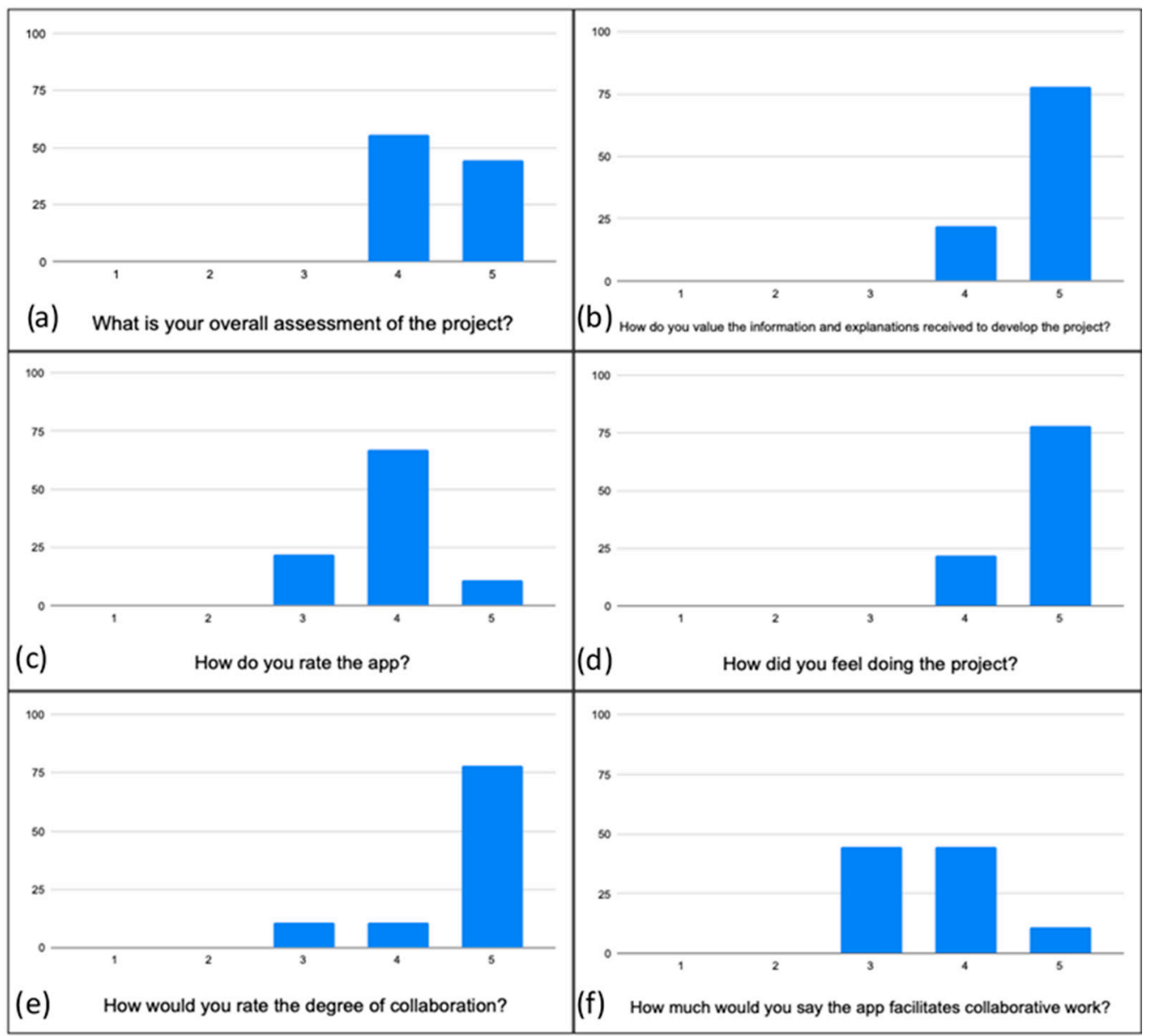

Figure 2. Satisfaction survey. (a) What is your overall assessment of the project? (b) How do you value the information and explanations received to develop the project? (c) How do you rate the app? (d) How did you feel doing the project? (e) How would you rate the degree of collaboration? (f) How much would you say the app facilitates collaborative work?

\subsection{Impact on Student Learning}

This section describes the data obtained through the three open questions of the satisfaction survey applied, grouping the similar answers in order to know the impact of the experience on the students' training.

The first question was: What difficulties have you encountered? The main answers were related to the individualisation of the work and the difficulty of using the app at the beginning of the programme. The individualisation of the work was encouraged by doing it remotely, as this provokes and facilitates the work by tasks, as another participant indicated. The second response showed the students' need for training in the use of educational apps, despite living in the digital age. This need was expressed in other questions of the survey. However, at the end of the programme, $100 \%$ of the participants claimed to improve their ability to collaborate, as well as expressing the need for ICT training.

Other difficulties were learning in a new environment with a different dynamic, as the app gave them some small errors and the information to be worked on seemed complex. Several students indicated that they did not have any complications.

The second question sought to know what they had learned. The answers were varied and showed an achievement of the competences proposed to be developed in the programme: improvement in the use of CAT tools and online collaborative work. In addition, they claimed to have learned new ways of teaching and working in a creative way, to know an interesting and useful collaborative app for their performance as a teacher. Information and concepts and an original and fun way of teaching music content. 
The last and third question sought to know what would they improve about the project? Some answers showed a lack of knowledge about the app and the video tutorials. For example, one of the answers explained that their group used another platform for videoconferencing, when in the video tutorial 1, it was explained that the MIRO app has different tools, among them, videoconferencing. They also wrote that it would be interesting to include a chat that records conversations about work because in the end they had them on WhatsApp. Another tool was explained in the video tutorial 1 and used by one group. Other answers suggested the possibility of seeing each other in person, improving communication between the orchestra and the groups or improving stage 1 as they found it repetitive because all members of the group had to do the same thing. This last answer could be related to one of the answers of the first question when talking about task-based work. In other words, as they were used to working by task distribution, not doing so seemed to them to be a waste of time.

On the other hand, in the observational register, the teacher collected data that corroborated the scores obtained by the group. All groups covered and produced the boards within the indicated deadlines. In addition, the activity log on the board indicated that all group members participated equally in the design and development of the project. Both at the beginning and during the process, students were enthusiastic and made comments such as "I think it's a great idea", "I was a bit lost, but watching the videos and talking to my classmates I understand everything" and "I'm delighted, it's a creative way to learn online".

\section{Discussion}

It is indisputable that the development of transversal competences is fundamental in the training of future teachers and, as stated in our research question, digital platforms facilitate this training. Different authors $[39,40]$ have pointed out the need for a context that allows for interaction and communication for a good development of these competences. Faced with the new situation of online teaching, brought about by COVID-19, teaching has been forced to seek and create new forms and spaces that allow future teachers to develop them effectively. Several authors have pointed out the difficulty and complexity of creating spaces that enable the development of these transversal competences online [41,42]. However, authors such as $[43,44]$ proposed a new paradigm that links learning theories with technological tools based on a sociocultural vision of cognition that advocates that learning processes are essentially social in nature and are nourished by technology in terms of the potential it offers for creating, enriching or favouring interpersonal learning contexts, which they call computer-supported collaborative learning (CSCL).

If we take this paradigm into account, we find that ICTs offer new possibilities for social mediation, creating collaborative learning environments that enable students to carry out activities jointly and in an integrated way in the real world with real objectives [45].

Among the most significant results of this study, we can talk about the improvement of decision-making skills once the project is over. Among the competences that all future teachers should develop, decision-making abilities are fundamental for exercising educational leadership, enabling future teachers to be able to analyse and respond to the problems and needs of their own contexts and, thus, guide their educational practice. Authors such as Montero [46] affirm that teacher training should not be developed without knowledge of the characteristics of the teaching function, since throughout the active profession it is essential that teachers have the ability to make decisions regarding the group they manage in all curricular areas, so that the development of this competence during initial training is fundamental.

Furthermore, the results show that the development of competences through digital media is possible. However, in order for this to happen, knowledge of the tool is necessary, as well as the creation of dynamics and spaces that allow for interaction.

Based on this reality and the data obtained in our study, we can affirm that training future teachers in digital tools is essential for their good performance as teachers, as well 
as being key to a meaningful teaching-learning process. Authors such as García-Valcárcel and Hernández [44] who carry out research in this field agree on the need to situate technologies as a tool and not as an end in themselves, allowing students to learn more efficiently. Although it is true that this is a challenge, we must be aware that ICT can not only be a means for the development of transversal competences, but that, in recent years, the use of digital tools has been included in the curriculum as a transversal competence in itself [47].

It is important to point out, as can be seen in the results, that teachers are not aware of the need to master digital competence until they realise that their use of ICT is not sufficient for teaching. However, in this study we observed that there was a high degree of satisfaction in the use of these tools and in the motivation shown by students to participate in projects where ICTs guide educational practices. Baca [44] affirms that teachers who participate in collaborative learning projects using new technologies express a high level of satisfaction, highlighting the possibilities of communication and participation with pupils.

Some authors [48] have pointed out that one of the main barriers to the use of information and communication technologies in the teaching and learning process, as well as their optimal management and use, lies in the lack of acceptance and use by teachers due to their lack of training in them.

The lack of training in digital competences in initial teacher training is a major obstacle to learning and achieving technology-based competences $[49,50]$ and makes it considerably more difficult to reduce the digital divide [51].

It is necessary to guarantee the acquisition of digital competences in the training of future teachers in order to guarantee the use of new technologies in their future professional practice and enable the enrichment of learning [52,53].

The students participating in the service-learning project emphasised that the experience of collaborative creation and the fact of generating a real product enabled them to contextualise their future teaching activity. Undoubtedly, participation in this type of methodology favours the connection between theory and practice, facilitating the professional performance of graduates.

It is essential in today's labour market demands that students master the professional competences expected of them, as well as enhancing their social responsibility, which is why the use of a methodology such as a service-learning project works as a key tool [25].

With regard to the limitations posed by the study, we believe that both the sample and the timeframe were limited and that the next step would be to carry out a programme with a larger number of participants and over a longer period of time. It would also be of interest to establish comparisons between the effectiveness of different collaborative platforms in order to establish selection criteria according to the needs and the type of projects to be developed. We consider that this study can be presented as a reference for online university teaching through collaborative platforms, demonstrating that it is possible to develop competences that require a group and practical environment.

\section{Conclusions}

The current situation resulting from the global pandemic caused by COVID-19 has undoubtedly led to a change in the teaching and learning processes of university students. This has led to new alternatives, such as those presented in this study, using digital platforms that allow students to acquire the competency-based learning necessary for the development of their professional facet. We conclude that online environments through collaborative platforms are presented as a possibility for the development of competences in the teaching-learning modality of future teachers.

Author Contributions: Conceptualisation, S.D.-L. and S.F.-A.; methodology, M.A.-V. and S.F.-A.; formal analysis, J.-A.M.-M.; investigation, S.D.-L. and S.F.-A.; resources, M.A.-V.; data curation, J.-A.M.-M.; writing—original draft preparation, S.D.-L. and S.F.-A.; writing-review and editing, S.D.-L. and J.-A.M.-M.; visualisation, M.A.-V.; supervision, S.D.-L.; project administration, S.D.-L. All authors have read and agreed to the published version of the manuscript. 
Funding: This study was funded by Spanish Ministry of Science. Innovation and Universities through "Service learning and employability of university students in Spain: skills for job placement" project (grant number EDU2017-82629-R) and by Vigo University through "Teaching Innovation Groups" grants to the RED-IS (Red Educativa Docente- Innovar en Sociedad).

Institutional Review Board Statement: The study was conducted according to the guidelines of the Declaration of Helsinki.

Informed Consent Statement: Informed consent was obtained from all subjects involved in the study.

Data Availability Statement: The data are not publicly available to confidentiality reasons.

Acknowledgments: This article is derived from the research stay at the University of Granada within the programme of stays of the Vice Rectorate for Research and Transfer in the Department of Didactics and School Organisation.

Conflicts of Interest: The authors declare no conflict of interest.

\section{References}

1. Secundo, G.; Mele, G.; Vecchio, P.D.; Elia, G.; Margherita, A.; Ndou, V. Threat or opportunity? A case study of digital-enabled redesign of entrepreneurship education in the COVID-19 emergency. Technol. Forecast. Soc. Chang. 2021, 166, 120-565. [CrossRef]

2. García-Peñalvo, F.J.; Correll, A. La COVID-19 ¿enzima de la transformación digital de la docencia o reflejo de una crisis metodológica y competencial en la educación superior? Campus Virtuales 2020, 9, 83-98.

3. Crespi, P.; García-Ramos, J.M. Generic skills at university. Evaluation of a training program. Educ. XX1 2021, 24, 297-327. [CrossRef]

4. López-Ruiz, J.I. Un giro copernicano en la enseñanza universitaria: Formación por competencias. Rev. Educ. 2011, 356, $279-301$. [CrossRef]

5. Sepúlveda, A.; Opazo, M.; Díaz-Levicoy, D. Promoción de competencias transversales en la formación docente: Actividades y evaluación. Rev. Cuba. Educ. Super. 2019, 38.

6. Villa, A.; Poblete, M. Evaluación de competencias genéricas: Principios, oportunidades y limitaciones. Bordon 2011, 63, 147-170.

7. Martínez-Clares, P.; González-Morga, N. Las competencias transversales en la universidad: Propiedades psicométricas de un cuestionario. Educ. XX1 2018, 21, 231-262. [CrossRef]

8. García-Peñalvo, F.J.; Alarcón, H.; Domínguez, A. Active learning experiences in Engineering Education. Int. J. Eng. Educ. 2019, 35, 305-309.

9. Portillo, J.; Garay, U.; Tejada, E.; Bilbao, N. Self-Perception of the Digital Competence of Educators during the COVID-19 Pandemic: A Cross-Analysis of Different Educational Stages. Sustainability 2020, 12, 10128. [CrossRef]

10. Marin, V.; Reche, E. Universidad 2.0. Actitudes y aptitudes ante las TIC del alumnado de nuevo ingreso de la Escuela Universitaria de Magisterio de la UCO. Pixel Bit. Rev. Medios Educ. 2012, 40, 197-211.

11. Fernández-Márquez, E.; Vázquez-Cano, E.; López-Meneses, E.; Sirignano, F. La competencia digital del alumnado universitario de diferentes universidades europeas. Rev. Espac. 2020, 41, 1-15.

12. Portillo, J.; Lopez de la Serna, A. An international perspective for 'Improving teacher professional development for online and blended learning: A systematic meta-aggregative review. Educ. Technol. Res. Dev. 2020, 4, 1-4. [CrossRef]

13. Surià, R. Las TIC en las titulaciones universitarias de grado: Análisis del conocimiento y uso en el alumnado de la Universidad a Distancia. Rev. Electron. Investig. Psicoeduc. Psigopedag. 2010, 8, 1179-1200. [CrossRef]

14. Panagiotis, G.; Adamantios, P.; Efthymios, V.; Admos, A. Informatics and Communication Technologies (ICT) and In-service Teachers' Training. Rev. Eur. Stud. 2011, 3, 2-12. [CrossRef]

15. Janssen, J.; Bodemer, D. Coordinated Computer-Supported Collaborative Learning: Awareness and Awareness Tools. Educ. Psychol. 2013, 48, 40-55. [CrossRef]

16. Brazuelo, F.; Gallego, D.J. Mobile Learning: Los Dispositivos Móviles Como Recurso Educativo; Editorial MAD Eduforma: Sevilla, Spain, 2011; ISBN 978-84-676-5706-7.

17. López-Gil, M.M.; Bernal-Bravo, C. La cultura digital en la escuela pública. Rev. Interuniv. Profr. 2016, 30, $103-110$.

18. Villalonga, C.; Marta-Lazo, C. Modelo de integración educomunicativa de "APPs" móviles para la enseñanza y aprendizaje. Píxel-Bit. Rev. Medios. Educ. 2015, 46, 137-153. [CrossRef]

19. Zabala, A.; Arnau, L. Métodos para la Enseñanza de las Competencias; Graó: Barcelona, Spain, 2014; ISBN 978-84-998-0545-0.

20. Tejada, J. La formación de las competencias profesionales a través del aprendizaje servicio. Cult. Educ. 2013, 25, 285-294. [CrossRef]

21. Pino Juste, M. Metodologías Activas Como Clave en Los Procesos de Innovación en la Escuela. In Éxito Educativo: Claves de Construcción y Desarrollo; Santos Rego, M.A., Valle-Arias, A., Lorenzo Moledo, M., Eds.; Editorial Tirant lo Blanch: Valencia, Spain, 2019; pp. 129-150. ISBN 9788417508807.

22. Butin, D.W. The limits of service-learning in higher education. Rev. High. Ed. 2006, 29, 473-498. [CrossRef] 
23. Bringle, R.G.; Hatcher, J.A. Innovative practices in service learning and curricular engagement. New Dir. High. Educ. 2009, 147, 37-46. [CrossRef]

24. Carnicelli, S.; Boluk, K. The promotion of social justice: Service Learning for transformative education. J. Hosp. Leis. Sport Tour. Educ. 2017, 21, 126-134. [CrossRef]

25. Barrera, D.; Willner, L.N.; Kukahiko, K.I. Assessing the development of an emerging critical consciousness through service learning. J. Crit. Thought Prax. 2017, 6, 17-35. [CrossRef]

26. Aramburuzabala, P.; McIlrath, L.; Opazo, H. Embedding Service Learning in European Higher Education; Routledge: New York, NY, USA, 2019; ISBN 9781138089730.

27. Furco, A. El Aprendizaje-Servicio: Un enfoque equilibrado de la educación experiencial. Rev. Int. Investig. Educ. Glob. Desarro. 2011, 71-76.

28. Liesa, M. Descripción de escenarios de aprendizaje servicio en la universidad. Educ. Esp. 2009, 22, 267-280. [CrossRef]

29. Tedesco, J.C.; Tapia, M.N. El Aprendizaje- Servicio en la Educación Superior. In Una Mirada Analítica Desde los Protagonistas; EUDEBA Editorial Universitaria de Buenos Aires: Buenos Aires, Argentina, 2008.

30. Keen, C.; Kelly, H. Engaging with difference matters: Longitudinal college outcomes of co-curricular service-learning programs. J. High. Educ. 2008, 80, 59-79. [CrossRef]

31. De Prada Creo, E.; Mareque, M.; Portela-Pino, I. The acquisition of teamwork skills in university students through extra-curricular activities. Educ. Train. 2020, 63, 165-181. [CrossRef]

32. Souza, F.; Souza, D.; Costa, A. Investigação Qualitativa: Inovação, Dilemas e Desafíos; Editorial Ludomedia: Aveiro, Portugal, 2015.

33. Fernández-Aguayo, S. Drama como Técnica Terapéutica en Salud Mental: Diseño y Evaluación de un Programa. Ph.D. Thesis, University de Vigo, Vigo, Spain, 2018.

34. O'Neil, H.F., Jr.; Chung, G.K.W.K.; Brown, R. Use of Networked Simulations as a Context to Measure Team Competencies. In Workforce Readiness: Competencies and Assessment; O'Neil, H.F., Jr., Ed.; Erlbaum: Mahwah, NJ, USA, 1997; pp. 411-452.

35. O'Neil, H.F., Jr.; Lee, C.; Wang, S.; Mulkey, J. Final Reportfor Analysis of Teamwork Skills Questionnaire; Statistics Canada: Ottawa, ON, Canada, 1999. Available online: https:/ / core.ac.uk/download/pdf/5166182.pdf (accessed on 22 May 2021).

36. O'Neil, H.F., Jr.; Wang, S.; Chung, G.K.W.; Herl, H.E. Assessment of Teamwork Skills Using Computer-Based Teamwork Simulations. In Aircrew Training and Assessment; O'Neil, H.F., Jr., Andrews, D., Eds.; Lawrence Eribaum Associates: Mahwah, NJ, USA, 2000; pp. 245-276.

37. Krippendorf, K. Metodología de Análisis de Contenido. In Teoría y Práctica; Paidós: Barcelona, Spain, 1997; ISBN 84-7509-627-1.

38. Pino-Juste, M. Diseño y Evaluación de Programas Educativos en el Ámbito Social: Actividad Física y Dramaterapia; Alianza Editorial: Madrid, Spain, 2017; ISBN 1578-7001.

39. Royse, D.; Thyer, B.; Padgett, D. Program Evaluation. In An Introduction to an Evidence-Based Approach; Cengage Learning: Boston, MA, USA, 2016; ISBN13: 978-1-305-10196-8.

40. Gómez, E.M.; Sánchez, M.R.; García, J.L.A.; Hernández, S.G. Adquisición de competencias transversales a través de la tutoría en la universidad. Cuestión Univ. 2017, 9, 88-107.

41. Grunis, M.L.; Golovanova, I.I.; Kirilova, G.I.; Levina, E.Y.; Sizova, Z.M. Transformation of pedagogical communicative competence during creation digital online courses. Cont. Ed. Technol. 2021, 13, ep289. [CrossRef]

42. Pokrovskaia, N.N.; Leontyeva, V.L.; Babkova, M.Y.; Cappelli, L.; D’Ascenzo, F. Digital communication tools and knowledge creation processes for enriched intellectual outcome-experience of short-term E-learning courses during pandemic. Future Internet 2021, 13, 43. [CrossRef]

43. Kortabitarte, A.; Gillate, I.; Luna, U.; Ibáñez-Etxeberria, A. Las aplicaciones móviles como recursos de apoyo en el aula de ciencias sociales: Estudio exploratorio con el app "architecture gothique/romane" en educación secundaria. Ensayos 2018, 33, 65-79.

44. Varela-Odorica, S.; Valenzuela-González, J.R. Uso de las tecnologías de la información y la comunicación como competencia transversal en la formación incídalo de docentes. Educ. Electr. J. 2020, 24, 1-20. [CrossRef]

45. Montero, L. Profesores y profesoras en un mundo cambiante: El papel clave de la formación inicial. Rev. Educ. 2006, 340, 66-86.

46. García-Valcárcel, A.; Hernández, A. Recursos Tecnológicos Para la Enseñanza e Innovación Educativa; Síntesis: Madrid, Spain, 2013.

47. Baca, V.M. El proyecto Etwinning. Rev. Contrib. Cienc. Soc. 2010, 8. Available online: https://bit.ly/3dHkMjL (accessed on 22 May 2021).

48. Vìtolina, I. E-inclusion Process and Societal Digital Skill Development. Discourse Commun. Sustain. Educ. 2015, 6, 86-94. [CrossRef]

49. Garzón Artacho, E.; Martínez, T.; Ortega Martín, J.; Marín Marín, J.; Gómez García, G. Teacher Training in Lifelong Learning-The Importance of Digital Competence in the Encouragement of Teaching Innovation. Sustainability 2020, 12, 2852. [CrossRef]

50. Cantabrana, J.L.; Minguell, M.E.; Tedesco, J.C. Inclusión y cohesión social en una sociedad digital. Rev. Int. Tecnol. Educ. Sup. 2015, 12, 44-58. [CrossRef]

51. Castañeda, L.; Esteve, F.; Adell, J. ¿Por qué es necesario repensar la competencia docente para el mundo digital? Rev. Educ. Dist. 2018, 56, 1-20. [CrossRef] [PubMed]

52. Moreno-Guerrero, A.; Soler-Costa, R.; Marín-Marín, J.; López-Belmonte, J. Flipped learning and good teaching practices in secondary education. Comunicar 2021, 29. [CrossRef]

53. Papanikolaou, K.; Makri, K.; Roussos, P. Learning design as a vehicle for developing TPACK in blended teacher training on technology enhanced learning. Int. J. Educ. Technol. High. Educ. 2017, 14. [CrossRef] 